\title{
The properties of reservoir water in post-mining excavations of Cambrian and Devonian quartzite sandstones (Holy Cross Mountains)
}

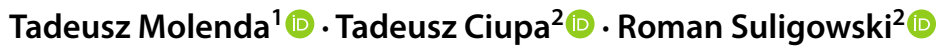

Received: 28 February 2019 / Accepted: 8 June 2020 / Published online: 18 June 2020

(c) The Author(s) 2020

\begin{abstract}
In the Holy Cross Mountains (southern Poland), there are numerous disused quarries. Some of these are filled with water, and some, despite their nearby location, have extremely diverse physicochemical and chemical properties of their waters. One such object is the Wiśniówka Mała reservoir. Its waters contain large amounts of sulfates (>700 mg/L) and iron $(24 \mathrm{mg} / \mathrm{L})$, which are weathering products of rocks containing metal sulfides (mainly pyrite) in the direct drainage zone. As a consequence, there is an increase in the electrolytic conductivity of the water supplying the reservoir, resulting in very low $\mathrm{pH}$ values $(<4)$. This article presents the detailed limnological characteristics of this reservoir and explains the process that led to its water acidification. A control reservoir, Barcza, was also selected for the tests. Although it is also a post-mining excavation, it has a neutral $\mathrm{pH}$ and a low concentration of sulfates and iron. The examined reservoirs differ in the hydrochemical type of waters. The Wiśniówka Mała reservoir represents a sulfate-calcium double-ion type $\left(\mathrm{SO}_{4}{ }^{2-}-\mathrm{Ca}^{2+}\right)$ and the Barcza reservoir, a bicarbonate-calcium type $\left(\mathrm{HCO}_{3}{ }^{-}-\mathrm{Ca}^{2+}\right)$. The concentrations of the main ions occurring here are shaped by the lithological features of the surrounding rocks (respectively: Upper Cambrian quartzite sandstones with pyrite mineralization zones, Lower Devonian sandstones cut by mudstones and claystones with tuffite inserts).
\end{abstract}

Keywords Pit lake $\cdot$ Water geochemistry $\cdot$ Water-rock interactions

\section{Introduction}

In recent years, the interest of many researchers has been focused on the water that fills the post-excavation pits in which the excavated materials were magma sedimentary rocks of various ages, including metal ores (Lentz 2002; Ramstedt et al. 2003; Pellicori et al. 2005; Stevens et al. 2005; Balistrieri et al. 2006; Hrdinka et al. 2013; Tucci and Gammons 2015) and rock raw materials (Hrdinka 2007; España et al. 2008; Molenda 2015; Jawecki et al. 2018;

Tadeusz Molenda, Tadeusz Ciupa and Roman Suligowski have contributed equally to this work.

Roman Suligowski

rsulig@ujk.edu.pl

1 Faculty of Earth Sciences, University of Silesia, Sosnowiec, Poland

2 Institute of Geography and Environmental Sciences, Jan Kochanowski University in Kielce, Uniwersytecka 7, 25-406 Kielce, Poland
Pociecha et al. 2018). The research results presented in these papers concern two main aspects, i.e., the occurrence of meromixing in the deeper reservoirs and a recognition of the selected features of water chemistry (Galas 2003; Boehrer and Schultze 2006; Molenda 2014a, b; Kubiak et al. 2018). After the exploitation of the raw materials and the following abandonment of the mines, most of them are flooded and become valuable natural water bodies (Luoma and Rainbow 2008). However, the water in some flooded quarries may be a local threat to the local natural environment (Nordstrom 2011, Migaszewski et al. 2014, 2018b), because it has unfavorable physical and chemical parameters (Migaszewski et al. 2007; España et al. 2008) and a high concentration of trace elements (Williams and Smith 2000; Bozau et al. 2004; Szarek-Gwiazda and Żurek 2006; Triantafyllidis and Skarpelis 2006; Migaszewski et al. 2008, 2016, 2018a, 2019). These include the reservoirs in which the properties of the water are determined by the course of natural geochemical processes that are caused by the presence of metal sulfides, mainly pyrite (the effect is a very low $\mathrm{pH}$ value) in the underground and acid mine drainage (AMD) (e.g., 
Johannesson and Zhou 1999; Blowes et al. 2003; Karakas et al. 2003; Migaszewski et al. 2013; Grawunder et al. 2014). This type of water reservoir, which is in the disused quarry of quartzite sandstones, is located in the Wiśniówka mining area in the Holy Cross Mountains (Poland). A few kilometers from this water reservoir, also in a closed sandstone

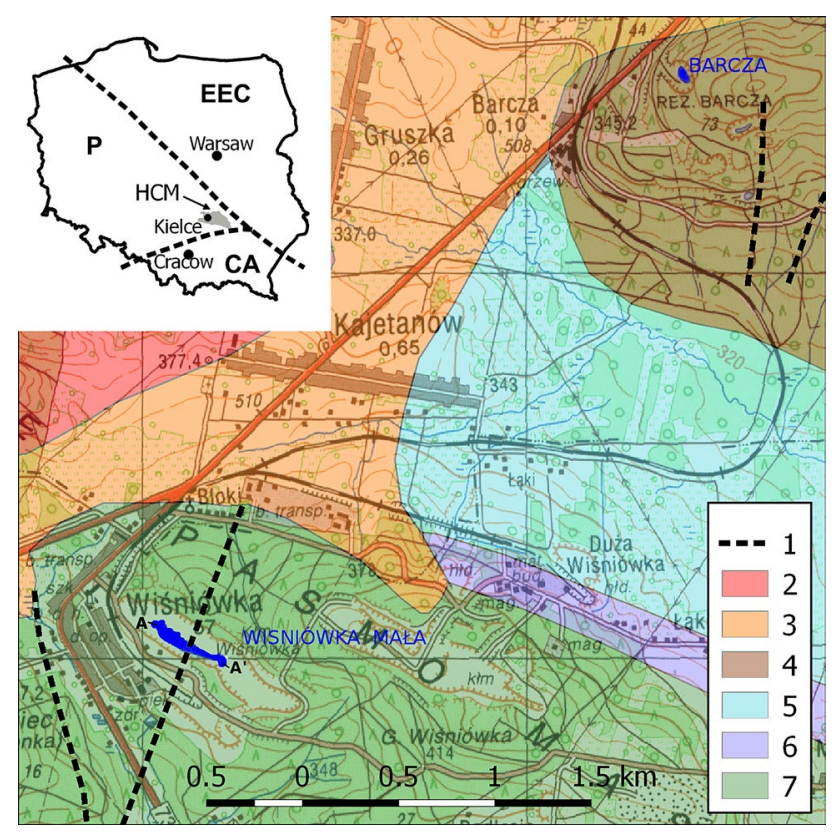

Fig. 1 Location of the water reservoirs Wiśniówka Mała and Barcza against: a the large geotectonic structures (Żylińska et al. 2006) HCM (Holy Cross Mountains), EEC (Precambrian East European Craton), P (Paleozoic, i.e. the Caledonian and Variscan fold belt), CA (Carpathian Alpine orogen) and $\mathbf{b}$ a simplified uncovered geological map (after Filonowicz 1973). 1-main faults, rock age: 2-Triassic, 3-Permian, 4-Devonian, 5-Silurian, 6-Ordovician, 7-Cambrian, $\mathrm{A}-\mathrm{A}^{\prime}-$-longitudinal profile quarry, but without traces of pyrite mineralization, a water reservoir (called Barcza) was created. Therefore, a comparative analysis of the physicochemical and chemical properties of the waters of these two reservoirs is both desirable and interesting.

\section{Materials and methods}

The objects of the research were two flooded quarriesWiśniówka Mała and Barcza, which were created as a result of the exploitation of various age-old sandstones in the Holy Cross Mountains (Fig. 1). The location of these water reservoirs is unique from a geological point of view. The Holy Cross Mountains are part of one of the most wellknown geotectonic structures in Europe-the Trans European Suture Zone (Berthelsen 1992; Nawrocki and Poprawa 2006; Żylińska et al. 2006). The mountains lie at the junction of two or, according to other authors, three great geological units (Stupnicka 1989; Kowalczewski and Dadlez 1996; Lamarche et al. 2002): the East European Precambrian Platform, the West European Platform of Paleozoic Consolidation and the Lesser Poland Bloc-in the rock mass and Alpine basins (Fig. 1a).

Location in the vicinity of the above units resulted in the formation of a complex system of tectonic structures, including the dislocation of the Holy Cross Mountains region and numerous transverse faults. At that time, igneous and hydrothermal phenomena occurred here (Kowalczewski and Dadlez 1996; Mizerski 1998).

The Wiśniówka Mała reservoir (Fig. 2a) is located in the Masłowskie Range within the Paleozoic core of the Łysogóry Block. Quartzitic sandstones from the middle and upper Cambrian (Furongian) with siltstone, clayey
Fig. 2 Wiśniówka Mała (a) and Barcza (b) reservoirs

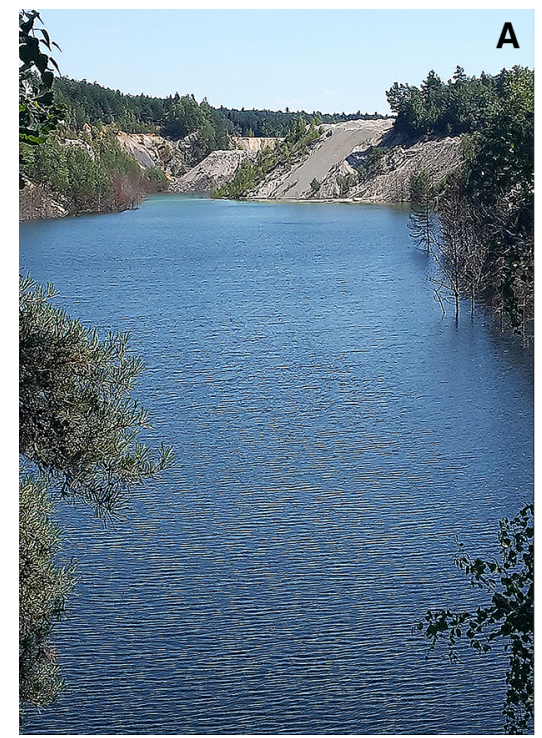


shale (with muscovite and illite), tuffite and bentonite interbeds are found in the area. Together, they form the Wiśniówka Sandstone Formation (Orłowski 1992; Żylińska et al. 2006). Detailed geochemical research conducted in the "Wiśniówka" mining area $\left(4.1 \mathrm{~km}^{2}\right)$ in recent years by Migaszewski et al. (2007, 2008, 2009, 2013, 2014, 2018a, b) indicate that within these rocks occur pyrite veins, wavellite and variscite accumulation, as well as many supergene minerals (iron oxyhydroxysulfates and oxyhydroxides). The detrital accessory minerals are dominated by zircon, rutile, monazite and tourmaline.

Currently, water from the drainage of the operating mine is used to rinse the extracted aggregate and then is discharged into the Wiśniówka Mała excavation. Its significant depth makes it possible to take post-mining waters of a considerable volume, despite the slope position of the quarry. However, no water leakage or dispersion outside of the boundaries of the mining area was observed (Migaszewski et al. 2016). This water has a very low $\mathrm{pH}(<4.0)$, which is caused by pyrite mineralisation zones in the discussed mining area, which was documented by Migaszewski and Gałuszka (2010) on the basis of detailed mineralogical and petrological studies of the rocks in the disused Podwiśniówka quarry in 2006.

In the Barcza quarry (Fig. 2b), which is located in the Klonowskie Range about four km NE of the Wiśniówka Mała, the extracted rocks were Lower Devonian (Emsian) sandstones and quartzitic sandstones with interbeds of mudstones and claystones, which are classified as the so-called Barczan Formation (Filonowicz 1973; Łobanowski 1990). The quarry has a thin layer of tuffites, which documents the volcanic activity in the Variscan orogeny (Kardymowicz 1960a; Fijałkowska-Mader and Malec 2018) that has a rare mineral called celadonite (Kardymowicz 1960b), which, when dissolved in the water of the reservoir, gives it a dark green colour. This small water reservoir has an almost oval shape. The groundwater inflow into the Barcza excavation is permanent, while the inflow of the surface water is periodic and mainly occurs in spring (thawing) and summer (precipitation). The periodic outflow of excess water from the reservoir is via a ditch. The reservoir, which is located in a forest complex, is part of an inanimate nature reserve that was established in 1984.

In 2016-2018, field hydrogeochemical studies were conducted in the characteristic seasons-spring and autumn (circulation period) as well as in summer and winter (stagnation period). The depths of the lakes were measured from a pontoon using a LOWRANCE HDS 5-Gen 2 echo sounder with a built-in GPS receiver. During the measurements, information about the depth and the coordinates of the point were recorded for each of the signals (impulses) that were sent by the sonar. It is a widely used technique that permits the quick and precise imaging of the bottom of water reservoirs. Bathymetric plans of the reservoirs were based on the sonar data using ArcMap 10.2.1. The same program allowed the transverse and longitudinal profiles of the examined objects to be drawn.

The basic physicochemical and chemical properties of water (temperature, $\mathrm{pH}$, electrolytic conductivity and turbidity) were measured directly in the field using a YSI multi-parameter EDS 6600 probe. The above-mentioned water parameters were determined in a vertical column in the reservoir every $1 \mathrm{~m}$ at the deepest section (Figs. 3, 4). Moreover, the transparency of the water was examined using a Secchi disc.

Water samples for the chemical analyses were taken from the surface layer directly into polyethylene bottles and from the bottom layer (about $0.5 \mathrm{~m}$ above the bottom) using an Eijkelkamp pressure gauge. Laboratory analyses of the chemical composition of the water were preceded by its filtration on a $0.45-\mu \mathrm{m}$ filter (Millipore). The content of the main cations and anions in the water: $\mathrm{Ca}^{2+}, \mathrm{Mg}^{2+}, \mathrm{Na}^{+}, \mathrm{K}^{+}$, $\mathrm{SO}_{4}{ }^{2-}, \mathrm{Cl}^{-}$was determined using a Metrohm 850 Professional IC ion chromatograph, $\mathrm{HCO}_{3}{ }^{-}$- titration method with b-r basicity indicator. Additionally, once (19 June 2017), the concentration of iron $\left(\mathrm{Fe}_{\text {tot }}\right)$ and selected trace elements were determined in the vertical column (every $2 \mathrm{~m}$ ) of the Wiśniówka Mała reservoir using an Inductively Coupled Plasma-Quadropole Mass Spectrometer (ICP-QMS; ELAN DRC II model, Perkin Elmer). A set of Perkin Elmer Multielement Calibration Standards solutions were used.

Classification of the hydrochemical types of water was based on the classification of Szczukariew-Prikłoński
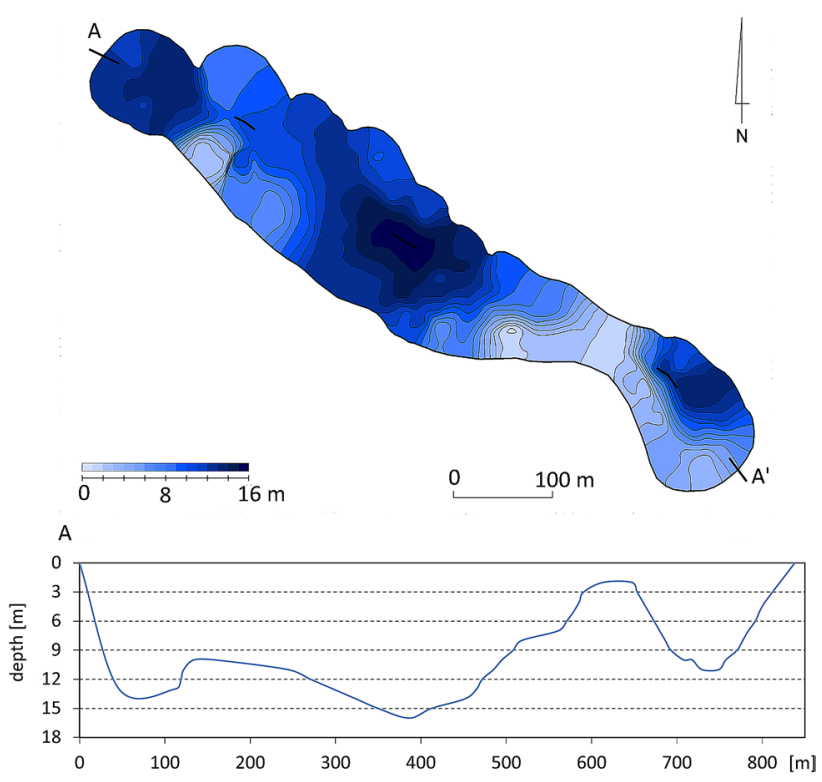

Fig. 3 Bathymetry of the Wiśniówka Mała reservoir. A-A'-longitudinal profile 
(Macioszczyk and Dobrzyński 2007). Basic statistical analyses were performed using the R (R Core Team 2014) program.

\section{Results and discussion}

The Wiśniówka Mała reservoir, an area of 5.2 ha, has an average depth of $10.9 \mathrm{~m}$, maximum depth of $16 \mathrm{~m}$ and the water table at approx. $366 \mathrm{~m}$ a.s.l. (Fig. 3).

The shoreline of the Barcza reservoir reflects the shape of the post-mining excavation. Compared with the Wiśniówka Mała, it is a shallow reservoir with an average depth of $2.9 \mathrm{~m}$ and a maximum depth of $6.5 \mathrm{~m}$ (Fig. 4). It is a reservoir with a small surface area of $0.3 \mathrm{ha}$, while the water table is at approximately $372 \mathrm{~m}$ a.s.l. The water supply of both lakes
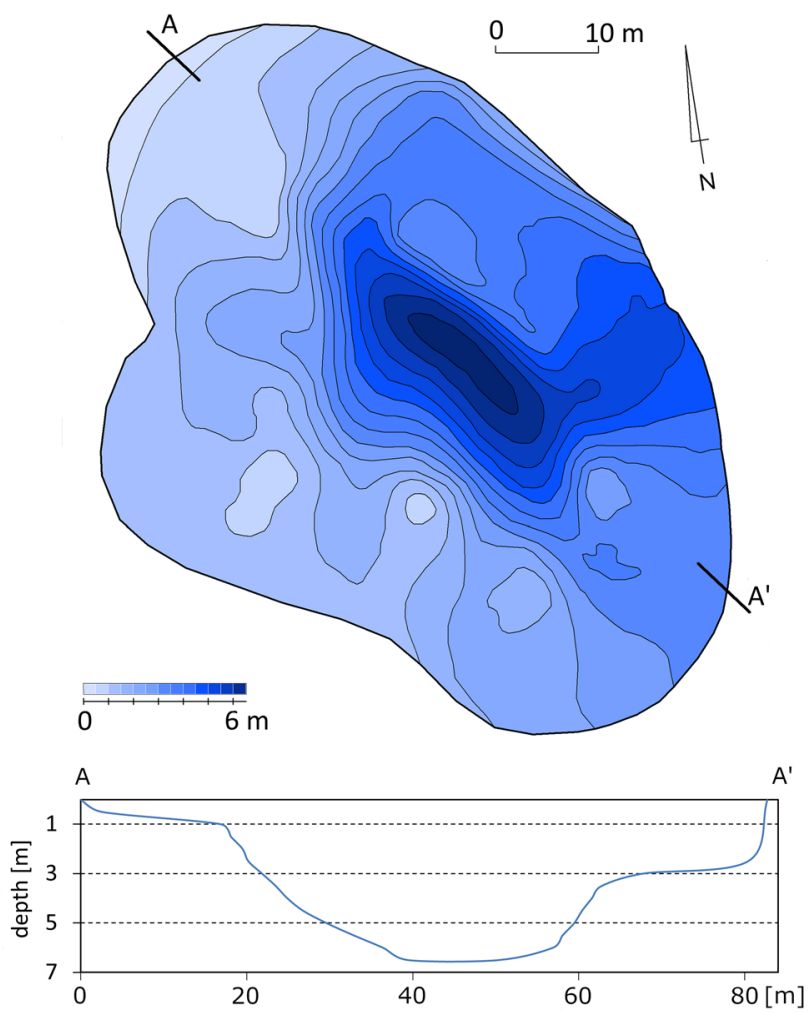

Fig. 4 Bathymetry of the Barcza reservoir. A- $\mathrm{A}^{\prime}-$ longitudinal profile occurs through the groundwater inflow and surface runoff from their direct catchments. In the case of the Wiśniówka Mała reservoir, there is also a forced water circulation that is associated with both the intake and discharge of water into the reservoir, on which there is a pumping station that captures water for the technological purposes of the mining plant. These waters are used to rinse the spoil, after which they are discharged into the reservoir as industrial waste. These waters are very heavily loaded with mineral slurry. The suspension is indicative of their turbidity, which is above $50 \mathrm{NTU}$. This corresponds to approximately $50 \mathrm{mg} / \mathrm{L}$ $\mathrm{SiO}_{2}$. Therefore, in the place where their water is discharged into the reservoir, an inflow fan has developed. It is very well visible on the bathymetric plan of the reservoir (Fig. 3).

The discharge of the technological waters also affects the transparency of the water in the reservoir. In the drop zone, the visibility of Secchi disk was only a few tens of centimetres and it increased as it moved away from the drop point. In the north-western part of the reservoir, the visibility varied from 1.2 to $4.0 \mathrm{~m}$. In addition to the discharge of the technological waters, in the south-eastern part of the reservoir, gangue rocks from the exploitation of an adjacent quarry are deposited. This caused a change in the original coastline of the reservoir. Within 20 years, the area of the reservoir decreased by about 2 ha. There are also other landfills in the direct basin of the reservoir. Their total area is about 8 ha.

According to the classification of Szczukariew-Prikłoński (Macioszczyk and Dobrzyński 2007), the water in the tested reservoirs is double ion. In the Wiśniówka Mała reservoir, it represents the sulfate-calcium type $\left(\mathrm{SO}_{4}{ }^{2-}-\mathrm{Ca}^{2+}\right)$, and in the Barcza reservoir, the bicarbonate-calcium type $\left(\mathrm{HCO}_{3}{ }^{-}-\mathrm{Ca}^{2+}\right)$. The different hydrochemical types are the result of the concentration of the main ions (Table 1).

In the water of the Wiśniówka Mała reservoir, no bicarbonate ions were found. There was a very high concentration of sulfate ions, whose average concentration was $706 \mathrm{mg} / \mathrm{L}$. For comparison, the mean concentration of this ion in the Barcza reservoir was only $7.4 \mathrm{mg} / \mathrm{L}$. The concentrations of the remaining ions $\left(\mathrm{Ca}^{2+}, \mathrm{Mg}^{2+}, \mathrm{Na}^{+}, \mathrm{K}^{+}, \mathrm{Cl}^{-}, \mathrm{NO}_{3}{ }^{-}\right)$ in the water of the Wiśniówka Mała reservoir were much higher than in the Barcza reservoir. However, no phosphate ions $\left(\mathrm{PO}_{4}{ }^{3-}\right)$ were found in the water of either reservoir (Table 1). The water of the Barcza reservoir represented a bicarbonate-calcium hydrochemical type, which is the most

Table 1 Median $\mathrm{pH}$, average EC and concentration of the main ions (mg/L) with the standard deviation (in parentheses) in the near-surface layer of the waters of the tested reservoirs $(n=6)$

\begin{tabular}{|c|c|c|c|c|c|c|c|c|c|c|c|}
\hline Reservoir & $\mathrm{pH}$ & $\begin{array}{l}\mathrm{EC} \\
\mu \mathrm{S} / \mathrm{cm}\end{array}$ & $\begin{array}{l}\mathrm{Ca}^{2+} \\
\mathrm{mg} / \mathrm{L}\end{array}$ & $\mathrm{Mg}^{2+}$ & $\mathrm{Na}^{+}$ & $\mathrm{K}^{+}$ & $\mathrm{HCO}_{3}^{-}$ & $\mathrm{Cl}^{-}$ & $\mathrm{NO}_{3}^{-}$ & $\mathrm{PO}_{4}{ }^{3-}$ & $\mathrm{SO}_{4}{ }^{2-}$ \\
\hline Wiśniówka Mała & $2.6(0.3)$ & 1389 (239) & $104.8(8.2)$ & $14.9(1.2)$ & $5.6(0.2)$ & $5.8(0.7)$ & $<0.1$ & $7.6(0.5)$ & $7.6(0.5)$ & $<0.1$ & 706.3 (101.4) \\
\hline Barcza & $6.0(0.3)$ & $66(12)$ & $8.6(1.2)$ & $1.2(0.4)$ & $1.2(0.1)$ & $1.6(0.1)$ & $18.0(1.4)$ & $3.5(0.2)$ & $3.5(0.2)$ & $<0.1$ & $7.4(1.8)$ \\
\hline
\end{tabular}


commonly occurring in nature (Allen 2008). This type of water is determined by the lithology of the basins and their catchments as well as anthropogenic influences. The Cambrian rocks in the Wiśniówka quarry, as was already mentioned, contain metal sulfides, primarily pyrite. The process of their weathering is responsible for the increase in the concentration of sulfate ions; the following chemical reaction describes this phenomenon (Garrels and Thompson 1960):

$\mathrm{FeS}_{2}+3.5 \mathrm{O}_{2}+\mathrm{H}_{2} \mathrm{O} \rightarrow \mathrm{Fe}^{2+}+2 \mathrm{SO}_{4}^{2-}+2 \mathrm{H}^{+}$,

$\mathrm{FeS}_{2}+14 \mathrm{Fe}^{3+}+8 \mathrm{H}_{2} \mathrm{O} \rightarrow 15 \mathrm{Fe}^{2+}+2 \mathrm{SO}_{4}^{2-}+16 \mathrm{H}^{+}$.

The oxidation of pyrite also releases considerable amounts of iron ions. The weathering of pyrite occurs on both the walls of the quarry and on the heaps that are located around the reservoir (Migaszewski et al. 2013). In the depressions in the neighboring quarry in Podwiśniówka, strongly acidic leachate waters $(<2 \mathrm{pH})$ of very high electrolytic conductivity $(>10,000 \mu \mathrm{S} / \mathrm{cm})$ were found (Migaszewski et al. 2007). A similar $\mathrm{pH}$ value was also found in the leachate that was related to the weathering of the sulfide minerals in quarries that are located in other regions of Poland (Molenda 2011). The source of low $\mathrm{pH}$ and the slightly increased content of metals and arsenic are also due to the technological waters that are discharged into the reservoir and that originate from rinsing the aggregate that is obtained from the Podwiśniówka quarry. The result is a very high content of As in the water of the Wiśniówka Mała reservoir, which reached $22.8 \mu \mathrm{g} / \mathrm{L}$ at the surface in June 2017 , and which increased with depth-in the bottom layer (at a depth of $12 \mathrm{~m}$ ) it was as much as $62.4 \mu \mathrm{g} / \mathrm{L}$ (Table 2). The concentrations of selected heavy metals and trace elements that were found in the vertical column (every $2 \mathrm{~m}$ ) in the deepest part of the Wiśniówka Mała reservoir are presented in Table 2. These concentrations were not related to the depth of the reservoir, except for the downward trend in the case of $\mathrm{Ba}$ and $\mathrm{Cu}$.

Differences in the physicochemical and chemical properties of the water in the studied reservoirs provide the best evidence of water mineralisation. The determined value of electrolytic conductivity in the Barcza reservoir $-66 \mu \mathrm{S} / \mathrm{cm}$ is comparable to that obtained in other post-mining lakes, including those located in crystalline rocks (Molenda 2014a). The electrolytic conductivity of the Wiśniówka Mała reservoir, however, was comparable to those found in the reservoirs that receive leachate from landfill sites that contain metal sulfides (Molenda 2011). It is worth noting that electrolytic conductivity increases with time. In 2005, the average value of the electrolytic conductivity in the surface water layer was $450 \mu \mathrm{S} / \mathrm{cm}$ (Migaszewski et al. 2009), in 2014-2016-1100 $\mu \mathrm{S} / \mathrm{cm}$ (Migaszewski et al. 2016), and currently, (2016-2018), it is $1389 \mu \mathrm{S} / \mathrm{cm}$. In 13 years, it has increased by more than $900 \mu \mathrm{S} / \mathrm{cm}$. During this period, there was also an increase in the iron concentration $\left(\mathrm{Fe}_{\text {tot. }}\right)$ from $0.3 \mathrm{mg} / \mathrm{L}$ in 2005 (Migaszewski et al. 2009) to $24 \mathrm{mg} / \mathrm{L}$ currently recorded. These changes result from rinsing the aggregate that is enriched with pyrite from the Wiśniówka Duża quarry.

In the vertical profile of the Wiśniówka Mała reservoir, the distribution of electrolytic conductivity in the summer is interesting (Fig. 6). In the thermocline layer, which was identified from the thermal profile, an apparent increase in the electrolytic conductivity of the water was observed. Under the influence of a temperature drop, the density of the water increased at this point, which caused a slowdown of the mineral particles sinking towards the bottom and influenced the increase in the electrolytic conductivity of the water. A similar process has also been observed in other reservoirs with a high water electrolytic conductivity (Molenda 2014b, 2018).

An analogous situation was not found in the case of the Barcza reservoir. The values of the electrolytic conductivity were aligned in the whole vertical profile; only in the zone above the bottom was a small increase observed (Fig. 6). Both in the spring and autumn, there were no apparent differences in the electrolytic conductivity in the vertical column in the case of both reservoirs, which testifies to the full mixing and homogenisation of the waters. This is a typical phenomenon for reservoirs that are located in the mid-latitudes.
Table 2 Concentration of $\mathrm{Fe}_{\text {tot }}$ and selected trace elements $(\mu \mathrm{g} / \mathrm{L})$ in the water column (every $2 \mathrm{~m}$ ) of the Wiśniówka Mała reservoir on 19 June 2017

\begin{tabular}{llllllllllllll}
\hline $\begin{array}{l}\text { Depth } \\
\mathrm{m}\end{array}$ & $\begin{array}{l}\mathrm{As} \\
\mathrm{\mu g} / \mathrm{L}\end{array}$ & $\mathrm{Ba}$ & $\mathrm{Cd}$ & $\mathrm{Co}$ & $\mathrm{Cr}$ & $\mathrm{Cu}$ & $\mathrm{Fe}_{\text {tot }}$ & $\mathrm{Mn}$ & $\mathrm{Ni}$ & $\mathrm{Pb}$ & $\mathrm{Tl}$ & $\mathrm{U}$ & $\mathrm{Zn}$ \\
\hline 0 & 22.8 & 11.4 & 1.05 & 207 & 112 & 828 & 24000 & 8739 & 198 & 0.73 & 0.35 & 16.8 & 309 \\
2 & 25.2 & 11.8 & 1.11 & 213 & 115 & 870 & 24800 & 9192 & 250 & 3.49 & 0.36 & 16.5 & 379 \\
4 & 55.0 & 8.99 & 1.05 & 210 & 117 & 811 & 28750 & 9285 & 227 & 1.66 & 0.30 & 16.3 & 316 \\
6 & 62.0 & 8.75 & 1.03 & 211 & 116 & 797 & 22000 & 9202 & 224 & 1.13 & 0.36 & 17.0 & 318 \\
8 & 59.5 & 8.54 & 1.01 & 209 & 118 & 793 & 28200 & 9435 & 225 & 0.64 & 0.34 & 16.2 & 300 \\
10 & 62.0 & 8.92 & 1.26 & 210 & 118 & 798 & 22550 & 9382 & 227 & 1.35 & 0.36 & 17.1 & 307 \\
12 & 62.4 & 8.51 & 1.06 & 208 & 116 & 788 & 25200 & 9288 & 225 & 0.64 & 0.33 & 16.1 & 298 \\
\hline
\end{tabular}


A characteristic feature of the Wiśniówka Mała reservoir was also the acid reaction of its water. During the study period, its median was $3.2 \mathrm{pH}$. For this reason, it was classified as acidotrophic. Similar, or even lower, $\mathrm{pH}$ values were found in other acidotrophic reservoirs that fill the bottoms of inactive post-mining excavations (Bednar et al. 2005; España et al. 2008) or those receiving acid leachate from industrial waste dumps (Molenda 2014b). The distribution of water in the vertical column of the Wiśniówka Mała reservoir was also unusual. In the summer, a drop in water $\mathrm{pH}$ in the thermocline was observed (Fig. 5), which is the result of the accumulation of sulphuric acid and pyrite oxidation products in the zone in which the density of water increased under the influence of a temperature drop. The decrease in $\mathrm{pH}$ was synchronous with an increase in mineralisation in the thermocline zone (Fig. 5).

In the Barcza reservoir, the $\mathrm{pH}$ was also acidic, and its median was $6.0 \mathrm{pH}$. This weak acid water reaction is characteristic of post-mining lakes whose basins are cut into crystalline rocks (Molenda 2015), which contain no buffering
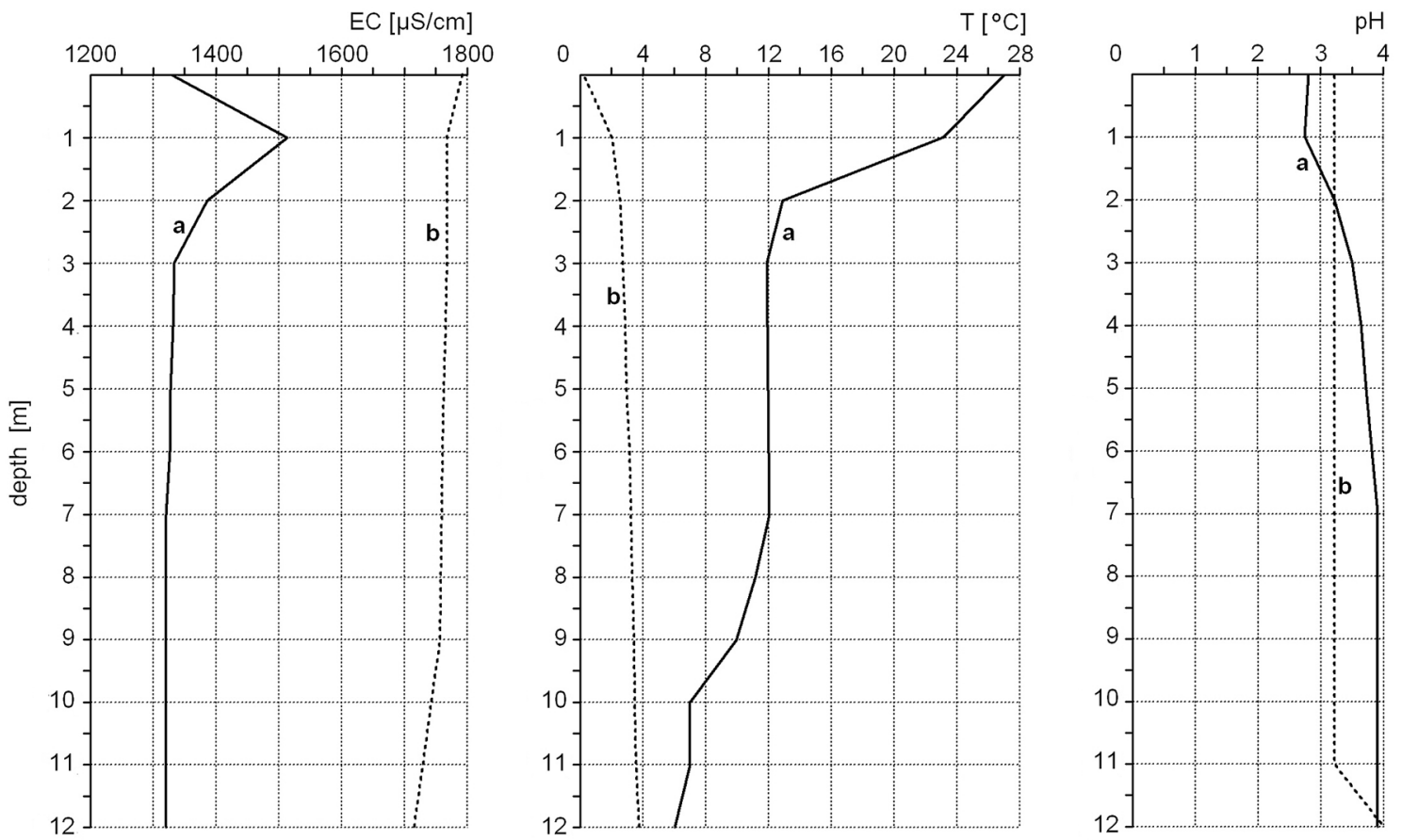

Fig. 5 Distribution of electrolytic conductivity, temperature and pH in the water column of the Wiśniówka Mała reservoir: a summer; $\mathbf{b}$ winter
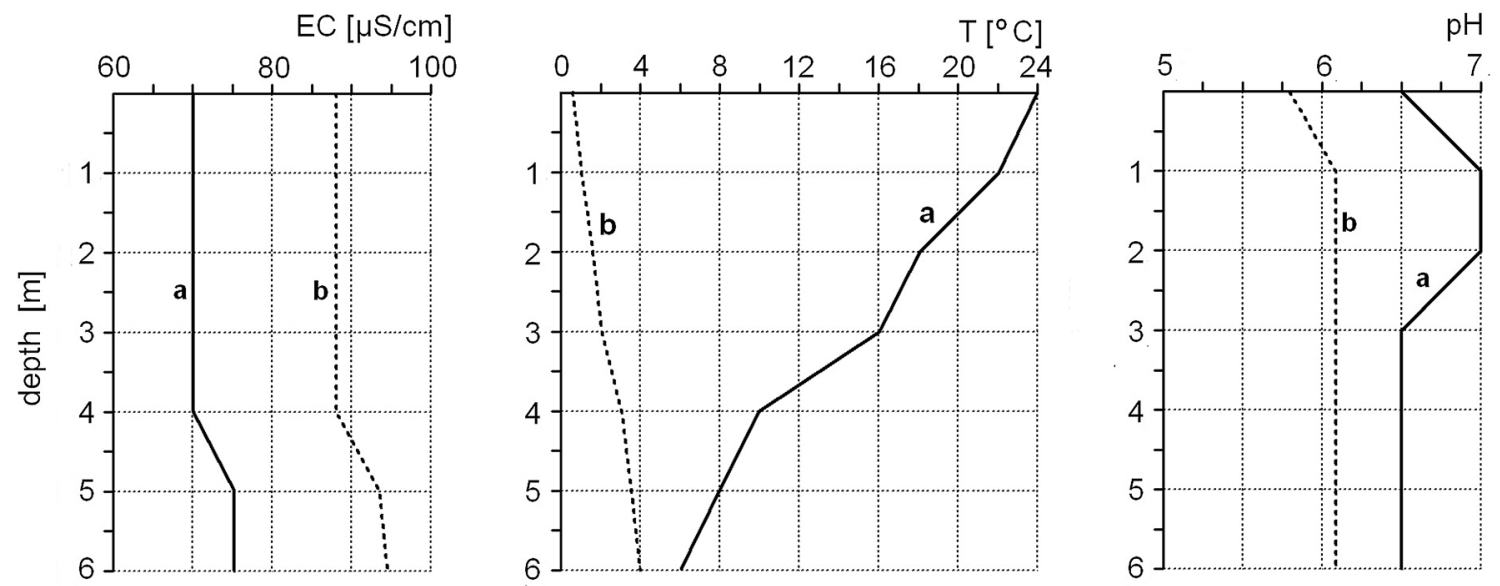

Fig. 6 Distribution of electrolytic conductivity, temperature and $\mathrm{pH}$ in the water column of the Barcza reservoir: a summer; $\mathbf{b}$ winter 
components, e.g., carbonates, and no mineralisation of metal sulfides, especially pyrites. The $\mathrm{pH}$ value of the water in these reservoirs corresponds approximately to the reaction of rainwater. In summer, an increase $\mathrm{pH}$ was found at a depth of $2 \mathrm{~m}$ (Fig. 6), which was a result of photosynthesis and $\mathrm{CO}_{2}$ consumption that was also responsible for water acidity.

The distribution of the water temperature in the vertical column of the Wiśniówka Mała reservoir was characteristic for particular seasons. In summer, stratification was found, and in winter-katothermy (Fig. 5) with a full mixing in spring and autumn. An analogous water temperature distribution was found in the Barcza reservoir (Fig. 6).

\section{Conclusions}

The chemical composition of the waters in the reservoirs that were formed in the excavations after the exploitation of quartzite sandstones in the Holy Cross Mountains (Poland) is determined by the course of the natural geochemical processes. In the Wiśniówka Mała, which is an endorheic reservoir that is fed with water coming from active mine drainage, there is a specific accumulation of $\mathrm{Fe}^{2+}, \mathrm{Fe}^{3+}$ and $\mathrm{SO}_{4}{ }^{2-}$ ions. These are the products of pyrite weathering in the zone of the underground surface drainage of the rock formation, which consequently leads to an increase in the electrolytic conductivity of the waters and very low $\mathrm{pH}$ values. On the other hand, in the Barcza reservoir, in which pyrite mineralisation does not occur in the surrounding rocks and the chemical composition of water is not modified by human intervention (nature reserve), the most common hydrochemical type of water, bicarbonate-calcium, has been formed.

Acknowledgements The authors are grateful to Professor Zdzisław M. Migaszewski and Professor Agnieszka Gałuszka (Division of Analytical Chemistry and Environmental Geochemistry, Jan Kochanowski University in Kielce) for supporting the research project, analysis of trace elements and their valuable remarks and suggestions, as well as Mgr inż. Stanisław Zieliński-head of the mining plant "Wiśniówka Mine in Wiśniówka" (Eurovia Kruszywa S.A.) for consenting to carry out research and the technical assistance in their implementation.

Open Access This article is licensed under a Creative Commons Attribution 4.0 International License, which permits use, sharing, adaptation, distribution and reproduction in any medium or format, as long as you give appropriate credit to the original author(s) and the source, provide a link to the Creative Commons licence, and indicate if changes were made. The images or other third party material in this article are included in the article's Creative Commons licence, unless indicated otherwise in a credit line to the material. If material is not included in the article's Creative Commons licence and your intended use is not permitted by statutory regulation or exceeds the permitted use, you will need to obtain permission directly from the copyright holder. To view a copy of this licence, visit http://creativecommons.org/licenses/by/4.0/.

\section{References}

Allen JP (2008) Biophysical chemistry. Wiley-Blackwell, London

Balistrieri LS, Tempel RN, Stillings LL, Shevenell LA (2006) Modeling spatial and temporal variations in temperature and salinity during stratification and overturn in Dexter Pit Lake, Tuscarora, Nevada, USA. Appl Geochem 21:1184-1203. https://doi. org/10.1016/j.apgeochem.2006.03.013

Bednar AJ, Garbarino JR, Ranville JF, Wildeman TR (2005) Effects of iron on arsenic speciation and redox chemistry in acid mine water. J Geochem Explor 85:55-62. https://doi.org/10.1016/j. gexplo.2004.10.001

Berthelsen A (1992) Tectonic evolution of Europe, From Precambrian to Variscan Europe. In: Blundell D, Freeman S, Mueller S (eds) A continent revealed: the European geotravers. Cambridge University Press, Cambridge, pp 153-164

Blowes DW, Ptacek CJ, Jambor JL, Weisener CG (2003) The geochemistry of acid mine drainage. Treat Geochem 9:149-204. https:// doi.org/10.1016/B0-08-043751-6/09137-4

Boehrer B, Schultze M (2006) On the relevance of meromixis in mine pit lakes. In: Barnhisel RI, editor. 7th international conference on acid rock drainage (ICARD), March 26-30, 2006. St. Louis, MO: Published by the American Society of Mining and Reclamation (ASMR), 3134 Montavesta Road, Lexington, pp 200-216

Bozau E, Leblanc M, Seidel JL, Stärk H-J (2004) Light rare earth elements enrichment in an acidic mine lake (Lusatia, Germany). Appl Geochem 19:261-271. https://doi.org/10.1016/S0883 $-2927(03) 00150-1$

Core Team R (2014) R: a language and environment for statistical computing. R Foundation for Statistical Computing, Vienna

España JS, Pamo EL, Pastor ES, Ercilla MD (2008) The acidic mine pit lakes of the Iberian Pyrite Belt: an approach to their physical limnology and hydrogeochemistry. Appl Geochem 23:1260-1287. https://doi.org/10.1016/j.apgeochem.2007.12.036

Fijałkowska-Mader A, Malec J (2018) Age of the lower devonian tuffite horizon from Barcza (Holy Cross Mts., S Poland). Przeglad Geologiczny 9:578-584. https://doi.org/10.7306/2018.8

Filonowicz P (1973) Geological map of Poland scale 1:50 000, sheet Kielce (815). Wyd. Geologiczne, Warszawa (in Polish)

Galas J (2003) Limnological study on a lake formed in a limestone quarry (Kraków, Poland). Pol J Environ Stud 12:297-300

Garrels RM, Thompson ME (1960) Oxidation of pyrite by iron sulfate solution. Am J Sci 258(A):57-67

Grawunder A, Merten D, Büchel G (2014) Origin of middle rare earth element enrichment in acid mine drainage-impacted areas. Environ Sci Pollut Res 21:6812-6823. https://doi.org/10.1007/s1135 6-013-2107-x

Hrdinka T (2007) Typology and potential utilization of anthropogenic lakes in mining pits in the Czech Republic. Limnol Rev 7:47-53

Hrdinka T, Šobr M, Fott J, Nedbalová L (2013) The unique environment of the most acidified permanently meromictic lake in the Czech Republic. Limnologica 43:417-426. https://doi. org/10.1016/j.limno.2013.01.005

Jawecki B, Dąbek PB, Pawęska K, Wei X (2018) Estimating water retention in post-mining excavations using LiDAR ALS data for the Strzelin quarry, in Lower Silesia. Mine Water Environ. https ://doi.org/10.1007/s10230-018-0526-0

Johannesson KH, Zhou XP (1999) Origin of middle rare earth element enrichments in acid waters of a Canadian High Arctic lake. Geochim Cosmochim Acta 63:153-165. https://doi.org/10.1016/ S0016-7037(98)00291-9

Karakas G, Brookland I, Boehrer B (2003) Physical characteristics of acidic mining lakes. Aquat Sci 65:297-307. https://doi. org/10.1007/s00027-003-0651-z 
Kardymowicz I (1960a) Tuffite from Barcza Mountain near Zagnańsk (Święty Krzyż Mountains). Geol Q 4:597-608 (in Polish, English summary)

Kardymowicz I (1960b) Celadonite from Barcza in the Holy Cross Mountains. Geol Q 4:609-619 (in Polish, English summary)

Kowalczewski Z, Dadlez R (1996) Tectonics of the Cambrian in the Wiśniówka area (Holy Cross Mts., Central Poland). Geol Q 40:23-46

Kubiak J, Machula S, Choiński A (2018) Particular example of meromixis in the anthropogenic reservoir. Carp J Earth Environ Sci 15:5-13. DOI: $10.26471 /$ cjees/2018/013/001

Lamarche J, Bergerat F, Lewandowski M, Mansy JL, Świdrowska J, Wieczorek J (2002) Variscan to Alpine heterogeneous palaeostress field above a major Palaeozoic suture in the Carpathian foreland (southeastern Poland). Tectonophysics 357:55-80. https ://doi.org/10.1016/S0040-1951(02)00362-1

Lentz RT. Physical limnology and geochemistry of two circum-neutral $\mathrm{pH}$ mine pit lakes in NE Washington. National Meeting of the America Society of Mining and Reclamation, Lexington KY, June 9-13, Published by ASMR, 2002, pp 309-325. https://doi. org/10.21000/JASMR02010309

Łobanowski H (1990) Lower Devonian terrains of clastic deposition in Poland and their affinities to other European Devonian palaeogeographic-facial provinces. Neues Jahrb Geol Paläontol 7:404-420. https://doi.org/10.1127/njgpm/1990/1990/404

Luoma SN, Rainbow PS (2008) Metal contaminants in aquatic environments. Science and lateral management. Cambridge University Press, Cambridge

Macioszczyk A, Dobrzyński D (2007) Hydrogeochemistry. Zone of active groundwater exchange. PWN, Warszawa (in Polish)

Migaszewski ZM, Gałuszka A (2010) Xenotime from the Podwiśniówka mine pit, Holy Cross Mountains (South-Central Poland). Mineralogia 41:3-9. https://doi.org/10.2478/v1000 2-010-0007-y

Migaszewski ZM, Gałuszka A, Pasławski P, Starnawska E (2007) An influence of pyrite oxidation on generation of unique acid pit water: a case study, Podwiśniówka quarry, Holy Cross Mountains (south-Central Poland). Pol J Environ Stud 16:407-421

Migaszewski ZM, Gałuszka A, Hałas S, Dołęgowska S, Dąbek J, Budzyk I, Starnawska E (2008) Geochemistry and stable sulfur and oxygen isotope ratios of the Podwiśniówka pit pond water generated by acid mine drainage (Holy Cross Mountains, southcentral Poland). Appl Geochem 23:3620-3634. https://doi. org/10.1016/j.apgeochem.2008.09.001

Migaszewski ZM, Gałuszka A, Hałas S, Dąbek J, Dołęgowska S, Budzyk I, Starnawska E, Michalik A (2009) Chemical and isotopic variations in the "Wiśniówka Mała" mine pit water, Holy Cross Mountains (South-Central Poland). Environ Geol 57:29-40. https://doi.org/10.1007/s00254-008-1279-z

Migaszewski ZM, Gałuszka A, Michalik A, Dołęgowska S, Migaszewski A, Hałas S, Trembaczowski A (2013) The use of stable sulfur, oxygen and hydrogen isotope ratios as geochemical tracers of sulfates in the Podwiśniówka acid drainage area (South-Central Poland). Aquat Geochem 19:261-280. https://doi.org/10.1007/ s10498-013-9194-7

Migaszewski ZM, Gałuszka A, Migaszewski A (2014) The study of rare earth elements in farmer's well waters of the Podwiśniówka acid mine drainage area (south-central Poland). Environ Monit Assess 186:1609-1622. https://doi.org/10.1007/s10661-013-3478-7

Migaszewski ZM, Gałuszka A, Dołęgowska S (2016) Rare earth and trace element signatures for assessing an impact of rock mining and processing on the environment: Wiśniówka case study, southcentral Poland. Environ Sci Pollut Res Int 23:24943-24959. https ://doi.org/10.1007/s11356-016-7713-y

Migaszewski ZM, Gałuszka A, Dołęgowska S (2018a) Arsenic in the Wiśniówka acid mine drainage area (south-central Poland)—mineralogy, hydrogeochemistry, remediation. Chem Geol 493:491-503. https://doi.org/10.1016/j.chemg eo.2018.06.027

Migaszewski ZM, Gałuszka A, Dołęgowska S (2018b) Stable isotope geochemistry of acid mine drainage from the Wiśniówka area (south-central Poland). Appl Geochem 95:45-56. https://doi. org/10.1016/j.apgeochem.2018.05.015

Migaszewski ZM, Gałuszka A, Dołęgowska S (2019) Extreme enrichment of arsenic and rare earth elements in acid mine drainage: case study of Wiśniówka mining area (south-central Poland). Environ Pollut 244:898-906. https://doi.org/10.1016/j.envpo 1.2018.10.106

Mizerski W (1998) Main problems of tectonics and tectogenesis of the Palaeozoic in the Holy Cross Mts (Central Poland). Przeglad Geologiczny 46:337-342 (in Polish)

Molenda T (2011) Natural and anthropogenic changes in physicochemical properties of water in post-mining aquatic environments. Silesian University, Katowice (in Polish, English summary)

Molenda T (2014a) Górka - the deepest $(41.7 \mathrm{~m})$ building raw materials pit lake in Poland. Morphometrical characteristic. Górnictwo Odkrywkowe 55:126-129 (in Polish, English summary)

Molenda T (2014b) Impact of saline mine water: development of a meromictic reservoir in Poland. Mine Water Environ 33:327-334. https://doi.org/10.1007/s10230-014-0262-z

Molenda T (2015) Conditions for development of anthropogenic meromictic reservoirs in the workings of crystalline rocks (based on the examples of the quarries of the Žulovská pahorkatina, NE Czech Republic). Environ Earth Sci 74:2259-2272. https://doi. org/10.1007/s12665-015-4217-x

Molenda T (2018) Impact of saline mine water: development of ameromictic pond, the Rontok Wielki reservoir, Poland. Mine Water Environ 33:327-334. https://doi.org/10.1007/s10230-018-0544-y

Nawrocki J, Poprawa P (2006) Development of Trans-European Suture Zone in Poland: from Ediacaran rifting to Early Palaeozoic accretion. Geol Q 50:59-76

Nordstrom DK (2011) Hydrogeochemical processes governing the origin, transport and fate of major and trace elements from mine wastes and mineralized rock to surface waters. Appl Geochem 26:1777-1791. https://doi.org/10.1016/j.apgeochem.2011.06.002

Orłowski S (1992) Cambrian stratigraphy and stage subdivision in the Holy Cross Mountains, Poland. Geol Mag 129:471-474

Pellicori DA, Gammons CH, Poulson SR (2005) Geochemistry and stable isotope composition of the Berkeley pit lake and surrounding mine waters, Butte, Montana. Appl Geochem 20:2116-2137. https://doi.org/10.1016/j.apgeochem.2005.07.010

Pociecha A, Bielańska-Grajner I, Szarek-Gwiazda E, Wilk-Woźniak E, Kuciel H, Walusiak E (2018) Rotifer diversity in the acidic pyrite mine pit lakes in the Sudety Mountains (Poland). Mine Water Environ 37:518-527. https://doi.org/10.1007/s10230-017-0492-y

Ramstedt M, Carlsson E, Lövgren L (2003) Aqueous geochemistry in the Udden pit lake, northern Sweden. Appl Geochem 18:97-108. https://doi.org/10.1016/S0883-2927(02)00068-9

Stevens CL, Fisher TSR, Lawrence GA (2005) Turbulent layering beneath the pycnocline in a strongly stratified pit lake. Limnol Oceanogr 50:197-206

Stupnicka E (1989) Regional Geology of Poland. Wydawnictwa Geologiczne, Warszawa (in Polish)

Szarek-Gwiazda E, Żurek R (2006) Distribution of trace elements in meromictic pit lake. Water Air Soil Poll 174:181-196. https://doi. org/10.1007/s11270-006-9091-4

Triantafyllidis S, Skarpelis N (2006) Mineral formation in an acid pit lake from a high-sulfidation ore deposit: Kirki, NE Greece. J Geochem Explor 88:68-71. https://doi.org/10.1016/j.gexpl o.2005.08.017

Tucci NJ, Gammons CH (2015) Influence of copper recovery on the water quality of the acidic Berkeley pit lake, Montana, U.S.A. 
Environ Sci Technol 49:4081-4088. https://doi.org/10.1021/es504 916n

Williams TM, Smith B (2000) Hydrochemical characterization of acute acid mine drainage at Iron Duke mine, Mazowe, Zimbabwe. Environ Geol 39:272-278. https://doi.org/10.1007/s002540050006

Żylińska A, Szczepanik Z, Salwa S (2006) Cambrian of the Holy Cross Mountains, Poland; biostratigraphy of the Wiśniowka Hill succession. Acta Geol Pol 56:443-461
Publisher's Note Springer Nature remains neutral with regard to jurisdictional claims in published maps and institutional affiliations. 